\title{
A Study on Dredged Sea Sand as an Optimum Replacement for Fine Aggregate in Concrete
}

\author{
R. Manigandan ${ }^{1}$, V. Srinivasan ${ }^{2}$ and K. C. Pazhani ${ }^{3}$ \\ ${ }^{1}$ PG Student, ${ }^{3}$ Associate Professor \\ ${ }^{1 \& 3}$ Department of Civil Engineering, College of Engineering, Anna University, Chennai, Tamil Nadu, India \\ ${ }^{2}$ Scientist, Advanced Materials Laboratory, CSIR-SERC, Chennai, Tamil Nadu, India \\ E-Mail: rmani3830@gmail.com,kcpazhani@annauniv.edu, vsriniserc@gmail.com
}

\begin{abstract}
This paper deals with the study and feasibility on utilization of dredged sea sand by conducting various experiments on physical properties like sieve analysis, gap grading. Chemical properties like percentage of organic content, chloride content, sulfur content, presence of deleterious material and volatile solids in dredged sea sand have been determined. The experiments like rapid chloride penetration test, water absorption test, alkalinity test, accelerated corrosion test, sulphur resistance test, acid resistance test, and sorptivity. Durability and strength of concrete have been studied by considering various properties of fine aggregate. The mix design have been done for M30 grade of concrete and the percentage of replacements $25 \%$, $50 \%, 75 \%$, and $100 \%$ of $M-S a n d$ (Manufacture Sand) of concrete specimen for all the experiments is considered. As we all know our current scenario of increase in demand of fine aggregate leads to scarcity of river sand. This has increased in research on dredged sea sand as a fine aggregate in concrete to reduce the demand on fine aggregate in construction industries. Comparative study of $M$-sand, river sand and dredged sea sand has been done. The dredged sand which is used for the study and testing is dredged to increase the sea bed depth of Ennor port for the accessibility of mother ship, it was collected from the coastal areas of Ennore Port (Kamarajar Port) and subjected to rain, and atmospheric conditions for a year.
\end{abstract}

Keywords: Compressive Strength, Tensile Strength, Flexural Strength, Water absorption

\section{INTRODUCTION}

Concrete is the most basic material required for construction of any structure. Sand which is used as fine aggregate in manufacturing of concrete is extracted from alluvial rivers or quarries. Due to the increasing construction, the requirement of concrete is increasing. So, the demand for sand is also increasing. The sources which are used for extraction of sand are depleting. The research reported here is on dredged sea sand, which is considered the most viable alternatives to river sand, with respect to availability, ease of extraction, environmental impact and cost. The dredged sea sand for this research work was obtained from the coastal areas of Ennore port (kamarajar port). The sand is dredged to increase the sea bed depth of the Ennore port for the accessibility of mother ships. Nearly 21 million cubic meters of sand should be dredged from Ennore port every year. The dredged sea sand obtained was for this project work was subjected to rain and atmospheric conditions for a year. Many countries like Sri Lanka, China and America are following the practice of using dredged sea sand as fine aggregate for different concrete works. The studies show that dredged sea sand was collected from 2 to $7 \mathrm{~km}$ away from the Western coast of Sri Lanka, after dredging can be used as an alternative to river sand. Experiments conducted on dredged sea sand collected from European and American coasts shows that this material can be used for construction of base and sub base pavements. Materials collected from marine deposits at coasts of Great Britain are already used for concrete production for a long time. In China, sea sand is used in local concrete works due to convenience and lower costs.

\section{DREDGED SEA SAND}

Dredged sea sand obtained from seabed it has two problems of Seashells \& Salt. Seashells are hard materials that can produce good quality concrete however higher cement content may be required due to angularity of the shell to obtain the desired workability. Aggregate containing complete shells should be avoided as their presence may result in voids in the concrete and lower the compressive strength. Generally, dredged sea sand containing large amount of chloride should not be used in reinforced concrete. Marine-dredged sand can be washed with fresh water to reduce the salt content.

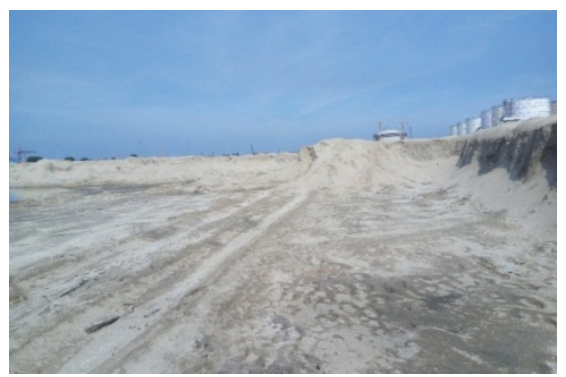

Fig.1 Dredged sea sand at Ennore Port

In the presence of the chloride it may affect the concrete by

1. Altering the time of set

2. Increasing drying shrinkage

3. Increasing the risk of corrosion of steel reinforcement causing efflorescence. 


\section{MATERIAL}

\section{A. Cement}

Cement which is used for the casting work is 53 grade OPC. The physical properties of cement are shown in Table 1. Aggregates are procured locally for the casting work of concrete specimens. The aggregates are tested for their properties in accordance with the IS standards. Locally available river sand is used as a fine aggregate for concrete. Also locally available coarse aggregates of two grades are used in the concrete i.e. $10 \mathrm{~mm}$ and $20 \mathrm{~mm}$. The sieve analysis of the fine aggregate is performed as per IS 2386 (1963).

TABLE I PHYSICAL PROPERTIES OF CEMENT
\begin{tabular}{|l|c|c|}
\hline \multicolumn{1}{|c|}{ Properties } & Results & $\begin{array}{c}\text { Specification as per } \\
\text { IS 2386-1963 }\end{array}$ \\
\hline Fineness in $\mathrm{m}^{2} / \mathrm{kg}$ & 351 & Min.225 \\
\hline $\begin{array}{l}\text { Initial setting time } \\
\text { in minutes }\end{array}$ & 35 & Min. 30 \\
\hline $\begin{array}{l}\text { Final setting } \\
\text { time in minutes }\end{array}$ & 240 & Max. 600 \\
\hline $\begin{array}{l}\text { 3days compressive } \\
\text { strength in Mpa }\end{array}$ & 28.75 & Min. 27 \\
\hline $\begin{array}{l}\text { 7days compressive } \\
\text { strength in Mpa }\end{array}$ & 39.85 & Min. 37 \\
\hline $\begin{array}{l}\text { 28 days compressive } \\
\text { strength in Mpa }\end{array}$ & 54.47 & Min. 53 \\
\hline
\end{tabular}

\section{B. Coarse Aggregate}

The sieve analysis results are shown in Table II for natural river sand. To determine fineness modulus and zone of the sand the tests are conducted.

\begin{tabular}{|c|c|c|c|c|}
\hline 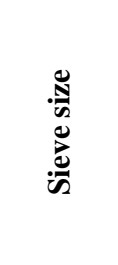 & 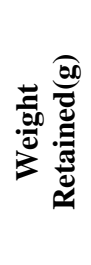 & 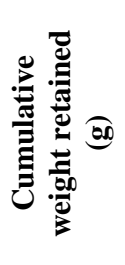 & 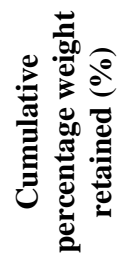 & 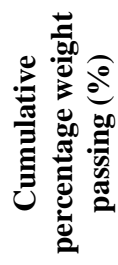 \\
\hline $80 \mathrm{~mm}$ & 0.0 & 0.0 & 0.0 & 100.0 \\
\hline $40 \mathrm{~mm}$ & 0.0 & 0.0 & 0.0 & 100.0 \\
\hline $20 \mathrm{~mm}$ & 0.0 & 0.0 & 0.0 & 100.0 \\
\hline $10 \mathrm{~mm}$ & 46.0 & 4.6 & 4.6 & 95.4 \\
\hline $4.75 \mathrm{~mm}$ & 875.0 & 87.5 & 92.1 & 7.9 \\
\hline $2.36 \mathrm{~mm}$ & 39.0 & 3.9 & 100.0 & 0.0 \\
\hline $1.18 \mathrm{~mm}$ & 0.0 & 0.0 & 100.0 & 0.0 \\
\hline $600 \mu \mathrm{m}$ & 0.0 & 0.0 & 100.0 & 0.0 \\
\hline $300 \mu \mathrm{m}$ & 0.0 & 0.0 & 100.0 & 0.0 \\
\hline $150 \mu \mathrm{m}$ & 0.0 & 0.0 & 100.0 & 0.0 \\
\hline Pan & 0.0 & 0.0 & - & 0.0 \\
\hline Total & 1000 & 100 & & \\
\hline \multicolumn{5}{|c|}{ Fineness modulus $=596.7 / 100=5.967$} \\
\hline
\end{tabular}

TABLE III SIEVE ANALYSIS RESULTS FOR 20 MM AGGREGATE

\begin{tabular}{|c|c|c|c|c|}
\hline 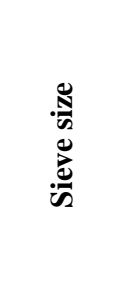 & 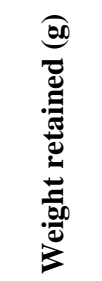 & 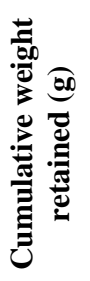 & 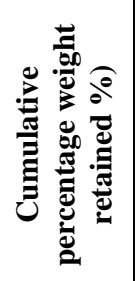 & 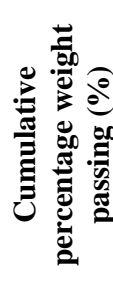 \\
\hline $80 \mathrm{~mm}$ & 0.0 & 0.0 & 0.0 & 100.0 \\
\hline $40 \mathrm{~mm}$ & 0.0 & 0.0 & 0.0 & 100.0 \\
\hline $20 \mathrm{~mm}$ & 660.0 & 33.0 & 33.5 & 100.0 \\
\hline $10 \mathrm{~mm}$ & 1270.0 & 63.5 & 96.5 & 67.5 \\
\hline $4.75 \mathrm{~mm}$ & 70.0 & 3.5 & 100.0 & 3.5 \\
\hline $2.36 \mathrm{~mm}$ & 0.0 & 0.0 & 100.0 & 0.0 \\
\hline $1.18 \mathrm{~mm}$ & 0.0 & 0.0 & 100.0 & 0.0 \\
\hline $600 \mathrm{~m}$ & 0.0 & 0.0 & 100.0 & 0.0 \\
\hline $300 \mathrm{~m}$ & 0.0 & 0.0 & 100.0 & 0.0 \\
\hline $150 \mathrm{~m}$ & 0.0 & 0.0 & 100.0 & 0.0 \\
\hline Pan & 0.0 & 0.0 & - & 0.0 \\
\hline Total & 2000 & 100 & & \\
\hline \multicolumn{5}{|c|}{ Fineness modulus $=729.5 / 100=7.295$} \\
\hline
\end{tabular}

\section{Fine Aggregate}

Test performed for determining the specific gravity for natural river sand. Results of these parameters for natural river sand are given in Table III.

TABLE IV SIEVE ANALYSIS RESULTS OF NATURAL RIVER SAND

\begin{tabular}{|c|c|c|c|c|}
\hline 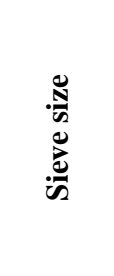 & 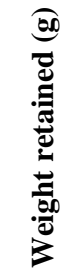 & 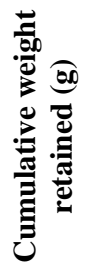 & 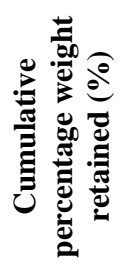 & 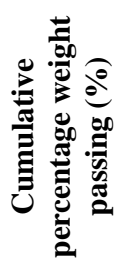 \\
\hline $4.75 \mathrm{~mm}$ & 40 & 4 & 4 & 96 \\
\hline $2.36 \mathrm{~mm}$ & 227 & 22.7 & 26.7 & 73.3 \\
\hline $1.18 \mathrm{~mm}$ & 35 & 3.5 & 30.2 & 69.8 \\
\hline $0.6 \mathrm{~mm}$ & 144 & 14.4 & 44.6 & 55.4 \\
\hline $0.3 \mathrm{~mm}$ & 308 & 30.8 & 75.4 & 24.6 \\
\hline $0.15 \mathrm{~mm}$ & 165 & 16.5 & 91.9 & 8.1 \\
\hline Pan & 81 & 8.1 & - & 0 \\
\hline Total & 1000 & 100 & 268.8 & - \\
\hline
\end{tabular}

TABLE V RESULTS OF NATURAL RIVER SAND

\begin{tabular}{|c|c|c|}
\hline Type of sand & Parameter & Result \\
\hline Natural river sand & Fineness modulus & 2.68 \\
\hline Natural river sand & Zone & 2 \\
\hline Natural river sand & Specific gravity & 2.6 \\
\hline Natural river sand & Water absorption test & $3 \%$ \\
\hline
\end{tabular}




\section{Dredged Sea Sand}

TABLE VI SIEVE ANALYSIS RESULTS OF THE DREDGED SEA

\begin{tabular}{|c|c|c|c|c|}
\hline \multicolumn{5}{|c|}{ SAND } \\
\hline $\begin{array}{l}\text { ज्ञ } \\
\text { के } \\
\text { ᄅे }\end{array}$ & 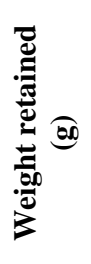 & 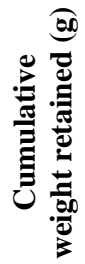 & 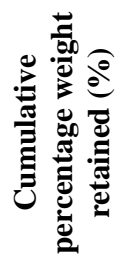 & 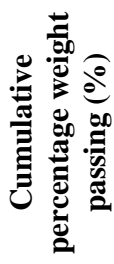 \\
\hline $4.75 \mathrm{~mm}$ & 40 & 4 & 4 & 96 \\
\hline $2.36 \mathrm{~mm}$ & 227 & 22.7 & 26.7 & 73.3 \\
\hline $1.18 \mathrm{~mm}$ & 35 & 3.5 & 30.2 & 69.8 \\
\hline $0.6 \mathrm{~mm}$ & 144 & 14.4 & 44.6 & 55.4 \\
\hline $0.3 \mathrm{~mm}$ & 308 & 30.8 & 75.4 & 24.6 \\
\hline $0.15 \mathrm{~mm}$ & 165 & 16.5 & 91.9 & 8.1 \\
\hline Pan & 81 & 8.1 & - & 0 \\
\hline Total & 1000 & 100 & 268.8 & - \\
\hline
\end{tabular}

The test is performed to determine the fineness modulus and zone of the dredged sea sand. Results are given in Table 6 and Table 7respectively

\section{TABLE VII SIEVE ANALYSIS RESULTS OF NATURAL RIVER SAND}

\begin{tabular}{|c|c|c|}
\hline Types of sand & Parameter & Result \\
\hline Dredged sea sand & Fineness modulus & 3.477 \\
\hline Dredged sea sand & Zone & 3 \\
\hline Dredged sea sand & Specific gravity & 2.591 \\
\hline
\end{tabular}

\section{CHEMICAL PROPERTIES OF DREDGED SEA SAND}

The chemical properties of dredged sea sand are investigated by two other laboratories and results are presented in Table 8 and 9 respectively. Sample taken for test $1 \mathrm{~kg}$, Moisture condition when received in Surface dry.

TABLE VIII CHEMICAL ANALYSIS RESULTS PROVIDED BY PUDHUVEAIL

\begin{tabular}{|c|l|c|c|c|}
\hline S. No. & \multicolumn{1}{|c|}{ Test Name } & Test Method & Test Result & $\begin{array}{c}\text { Specification Requirement } \\
\text { (IS 383-1970) }\end{array}$ \\
\hline 1. & Organic content & IS 2386: part-2 Cl-6.0 & Not detected & - \\
\hline 2. & Chloride (\%) & B.S. 812: P-117 & 0.004 & Max 0.04\% \\
\hline 3. & Sulfur as SO3(\%) & B.S.-812: p-118 & 0.0226 & Max 0.05\% \\
\hline 4. & $\begin{array}{l}\text { Presence of deleterious } \\
\text { material (\%) }\end{array}$ & IS 2386: P-2 Cl-2 \& 3 & 5.147 & Max 5\% \\
\hline 5. & Clay content & IS 3.25: P-18 & 0.05 & - \\
\hline
\end{tabular}

TABLE IX RESULTS OF CHEMICAL TEST FOR DREDGED SEA SAND PROVIDED BY PUDHUVEAIL

\begin{tabular}{|c|l|c|c|}
\hline $\begin{array}{c}\text { S. } \\
\text { No. }\end{array}$ & \multicolumn{1}{|c|}{ Test description } & $\begin{array}{c}\text { Results } \\
(\mathbf{\%})\end{array}$ & $\begin{array}{c}\text { Requirement as } \\
\text { per IS 383 (\%) }\end{array}$ \\
\hline 1. & Coal and Lignite & Nil & Max 1\% \\
\hline 2. & Clay lumps & Nil & Max 1\% \\
\hline 3. & Material finer than 75 & 1.5 & Max 3\% \\
\hline 4. & Shale & 6.60 & Max 1\% \\
\hline 5. & $\begin{array}{l}\text { Total \% of all } \\
\text { dexterous material }\end{array}$ & 8.10 & Max 5\% \\
\hline
\end{tabular}

\section{CONCRETE MIX DESIGN}

The concrete mix proportioning using dredged sea sand is not different than the usual mix design of concrete using natural river sand. All the constituents are same for both the cases i.e. concrete using dredged marine sand and natural river sand. The mix design is done based on provisions of IS 10262.The w/c ratio is selected 0.5 for M30 grade concrete. No super plasticizer is used for M30 grade concrete. Table 11 presents concrete mix proportioning for concrete grades and for all concrete mixes respectively.

TABLE X CONCRETE MIX PROPORTION

\begin{tabular}{|c|c|c|c|c|c|}
\hline $\begin{array}{l}\text { Grade of } \\
\text { concrete }\end{array}$ & $\mathrm{w} / \mathrm{c}$ ratio & $\begin{array}{c}\text { Water content } \\
\left(\mathrm{kg} / \mathrm{m}^{3}\right)\end{array}$ & $\begin{array}{c}\text { Cement content } \\
\left(\mathrm{kg} / \mathrm{m}^{3}\right)\end{array}$ & $\begin{array}{c}\text { Fine aggregate } \\
\left(\mathrm{kg} / \mathrm{m}^{3}\right)\end{array}$ & $\begin{array}{c}20 \mathrm{~mm} \text { aggregate } \\
\left(\mathrm{kg} / \mathrm{m}^{3}\right)\end{array}$ \\
\hline M30 & 0.5 & 197 & 437.78 & 666.52 & 1142.69 \\
\hline
\end{tabular}

\section{TESTING}

\section{A. Compressive Strength (Cube Strength)}

Size of the specimen was $150 \mathrm{~mm} \times 150 \mathrm{~mm} \times 150 \mathrm{~mm}$ for the compression test. The test was carried on cube specimen in percentage of replacement of $100 \%, 75 \%, 50 \%$, and $25 \%$ of dredged sea sand.

The bearing surfaces of the testing machine were wiped clean. While placing the cubes in the machine, care was taken such that the load was applied to opposite sides of the 
cubes as casted and not to the top and bottom. The axis of the specimen was carefully aligned with the center of the thrust of the spherically seated plate. As the spherical-seated block is to the specimen, the movable portion was the rotated gently by hand, so that uniform seating was obtained. The maximum load applied to the specimen was recorded and type of failure was also noted. The compressive strength of the specimen was calculated by using formula.

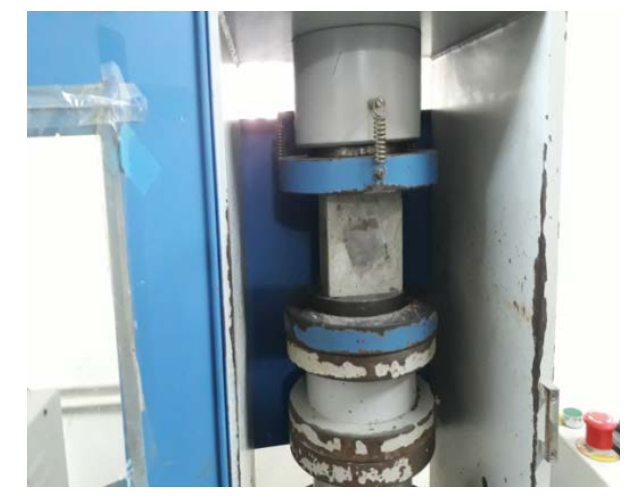

Fig. 2 Compression Testing Machine

Where

$$
\mathrm{f}=\mathrm{P} / \mathrm{A} \mathrm{N} / \mathrm{mm}^{2}
$$

$\mathrm{f}=$ compressive stress in $\mathrm{N} / \mathrm{mm}^{2}$

$\mathrm{p}=$ load at which specimen fails in $\mathrm{N}$

$\mathrm{A}=$ Area over which the load is applied in $\mathrm{mm}^{2}$

TABLE XI COMPRESSIVE STRENGTH

\begin{tabular}{|c|c|c|c|c|c|}
\hline \multirow{3}{*}{ Specimen } & \multirow{2}{*}{$\begin{array}{l}\text { Age of } \\
\text { curing } \\
\text { in days }\end{array}$} & \multicolumn{4}{|c|}{$\begin{array}{c}\text { Percentage of replacement of } \\
\text { dredged sea sand }\end{array}$} \\
\cline { 2 - 6 } & $\mathbf{1 0 0 \%}$ & $\mathbf{7 5 \%}$ & $\mathbf{5 0 \%}$ & $\mathbf{2 5 \%}$ \\
\hline \multirow{3}{*}{ D1 } & 7 & 27.68 & 27.96 & 28.12 & 28.99 \\
\cline { 2 - 6 } & 14 & 33.24 & 33.65 & 33.63 & 34.11 \\
\cline { 2 - 6 } & 28 & 38.96 & 37.22 & 38.01 & 38.56 \\
\hline \multirow{3}{*}{ D2 } & 7 & 27.72 & 27.79 & 27.89 & 28.00 \\
\cline { 2 - 6 } & 14 & 34.30 & 34.96 & 35.12 & 36.22 \\
\cline { 2 - 6 } & 28 & 39.16 & 40.77 & 40.96 & 41.00 \\
\hline \multirow{3}{*}{ D3 } & 7 & 27.70 & 27.89 & 26.33 & 27.98 \\
\cline { 2 - 6 } & 14 & 34.31 & 34.65 & 35.12 & 35.64 \\
\cline { 2 - 6 } & 28 & 39.66 & 39.95 & 40.23 & 41.12 \\
\hline
\end{tabular}

\section{B. Split Tensile Test (Cylinder Strength)}

The cylindrical specimens were tested for split tensile strength after 7, 14, 28days of curing. Specimens were tested immediately after taking out from the water.

Where,

$$
\text { Tensile strength }=(2 \mathrm{P} / \mathrm{\Pi DL}) \mathrm{N} / \mathrm{mm}^{2}
$$

$\mathrm{P}=$ load at which specimen fails in $\mathrm{N}$

$\mathrm{L}=$ length of the cylinder in $\mathrm{mm}$

$\mathrm{D}=$ diameter of the cylinder in $\mathrm{mm}$

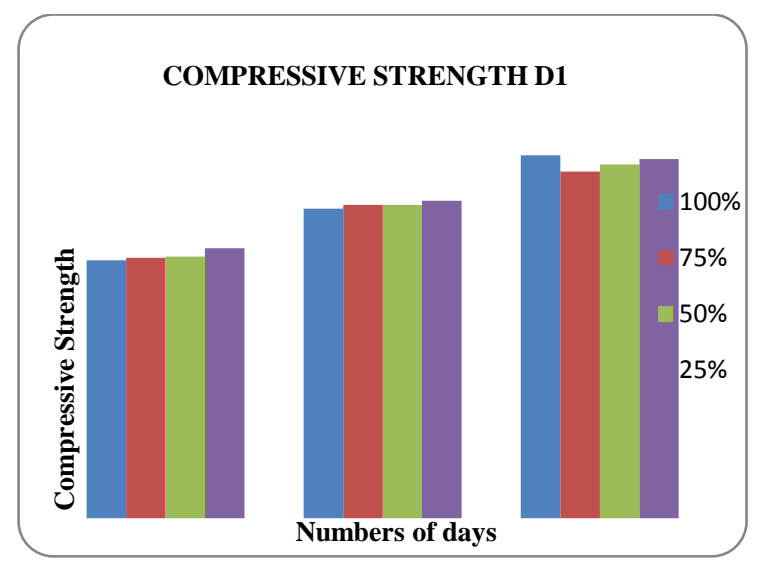

Fig. 3 Percentage of Change of Compression Strength (D1)

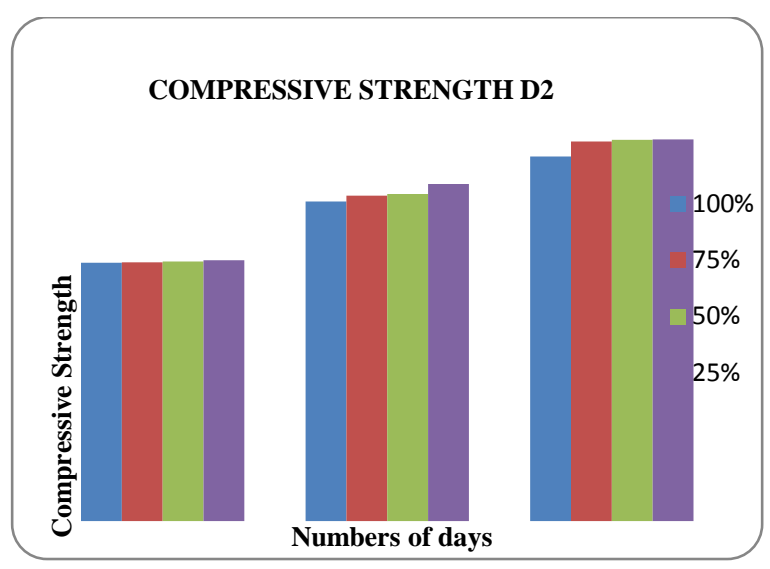

Fig. 4 Percentage of Change of Compression Strength (D2)

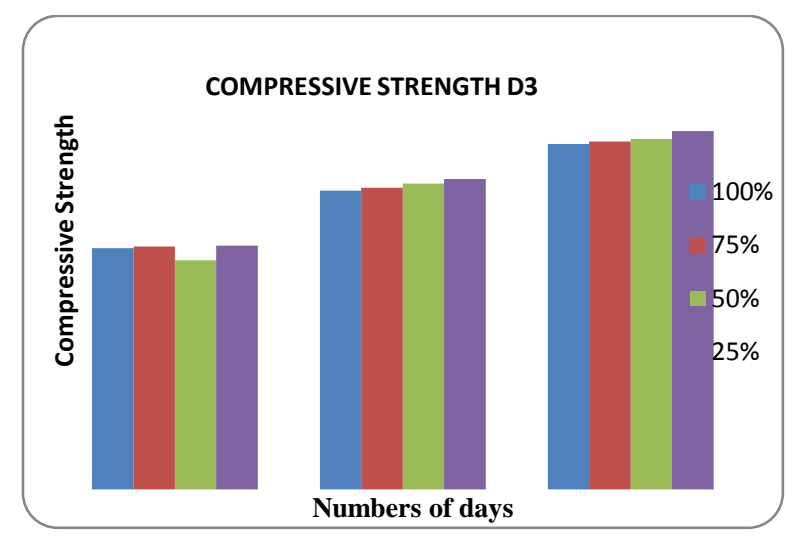

Fig. 5 Percentage of Change of Compression Strength (D3)

TABLE XII SPLIT TENSILE STRENGTH ON CYLINDER

\begin{tabular}{|c|c|c|c|c|c|c|}
\hline \multirow{3}{*}{ Specimen } & \multirow{2}{*}{$\begin{array}{c}\text { Load on } \\
\text { cylinders } \\
\text { (KN) }\end{array}$} & \multirow{2}{*}{ Days } & \multicolumn{4}{|c|}{$\begin{array}{c}\text { Split tensile } \\
\text { strength(N/mm }\end{array}$} \\
\cline { 4 - 7 } & & $\mathbf{2 5 \%}$ & $\mathbf{5 0 \%}$ & $\mathbf{7 5 \%}$ & $\mathbf{1 0 0 \%}$ \\
\hline \multirow{3}{*}{ Cylinder } & 105 & 7 & 4.18 & 3.56 & 3.12 & 2.98 \\
\cline { 2 - 7 } & 115 & 14 & 4.49 & 3.89 & 3.32 & 3.49 \\
\cline { 2 - 7 } & 120 & 28 & 5.39 & 5.02 & 4.82 & 4.49 \\
\hline
\end{tabular}




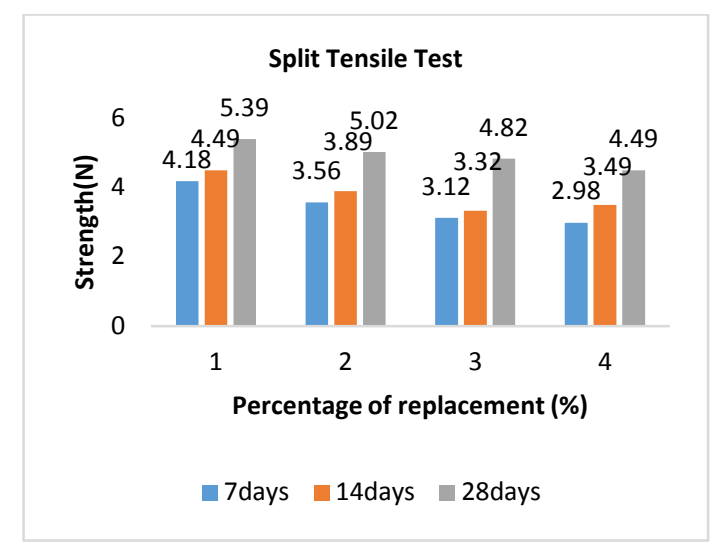

Fig. 6 Percentage of Change of Tensile Strength

\section{Flexural Test (Beam Strength)}

The beam specimens were tested for flexural strength after $7,14,28 d a y s$ of curing. The size of the specimen was $100 \mathrm{~mm} \times 100 \mathrm{~mm} \times 500 \mathrm{~mm}$. The specimen were submerged in clean fresh water in a curing tank and kept until the test. The specimen are tested immediately on removal from the water whilst they are still in a wet condition. The dimension of the specimen and their weigth were recorded before testing.Three specimens were tested for each percentage and average was taken

Where

$$
\text { Flexural strength }=\mathrm{PL} / \mathrm{bd}^{2} \mathrm{~N} / \mathrm{mm}^{2}
$$

$\mathrm{P}=$ load at which specimens fails in $\mathrm{N}$

$\mathrm{L}=$ Efffective span in $\mathrm{mm}$

$\mathrm{b}=$ Breadth of the specimens

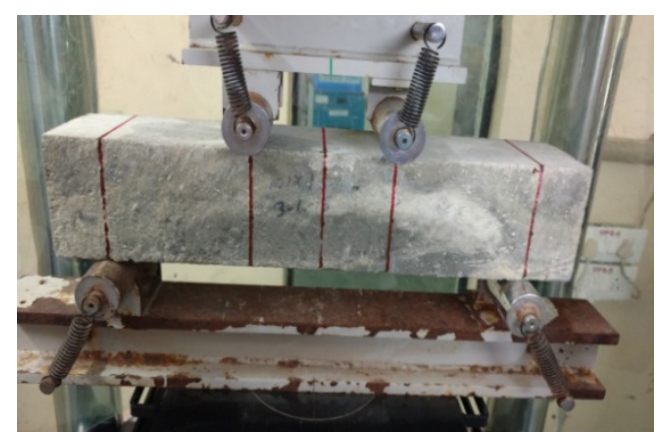

Fig. 7 Flexural Testing Machine

TABLE XIII FLEXURAL STRENGTH ON BEAM

\begin{tabular}{|c|c|c|c|c|c|c|}
\hline \multirow{2}{*}{ Specimen } & \multirow{2}{*}{ Days } & \multirow{2}{*}{$\begin{array}{c}\text { Load on } \\
\text { beam } \\
\end{array}$} & & \multicolumn{4}{|c|}{ Flexural strength $\mathbf{( N / \mathbf { m m } ^ { 2 } )}$} \\
\cline { 4 - 7 } & & $\mathbf{2 5 \%}$ & $\mathbf{5 0 \%}$ & $\mathbf{7 5 \%}$ & $\mathbf{1 0 0 \%}$ \\
\hline \multirow{3}{*}{ Beam } & 7 & 105 & 9.86 & 9.56 & 9.16 & 9.10 \\
\cline { 2 - 7 } & 14 & 112 & 9.89 & 9.64 & 9.23 & 9.11 \\
\cline { 2 - 7 } & 28 & 121 & 10.06 & 9.91 & 9.22 & 9.20 \\
\hline
\end{tabular}

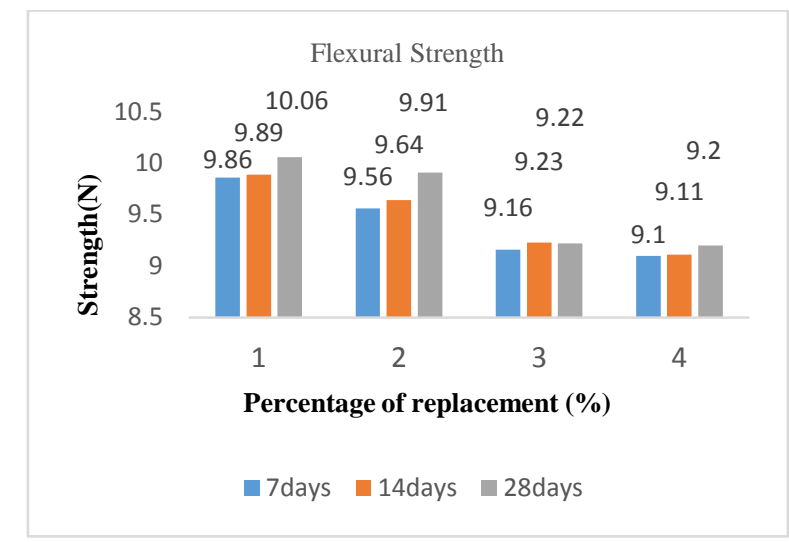

Fig. 8 Percentage of Change of Flexural Strength

\section{Acid Resistance Test}

The plain concrete specimens are exposed in the acid tank for required ages in months. After completion of exposure, the specimens are taken out of the acid tank. The required exposure ages considered for plain concrete specimens are 7days, 14 days, 28days respectively.

The acid which is used for the test is Sulfuric acid (H2SO4) solution having $5 \%$ concentration by volume of water. [22] The solution is stirred every week and $\mathrm{pH}$ value of solution is measured after every 3days. Modification in the $\mathrm{pH}$ is done by adding acid or water in the tank if $\mathrm{pH}$ value differs from Fig.9 show acid tank with concrete specimens for acid exposure and digital $\mathrm{pH}$ measuring device respectively.

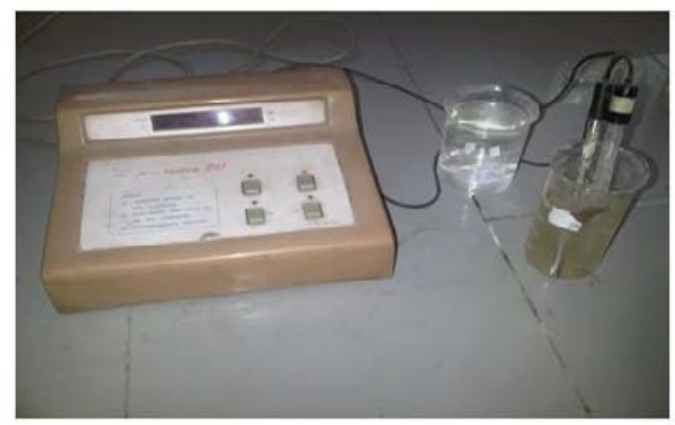

Fig. 9 Tank of Acid Solution with Concrete Specimen

All the specimens are weighed before keeping them into the acid tank. After removing from the tank of acid solution after completion of exposure, respective specimens are wiped clean and weighed. This weight is considered as a final weight of concrete specimens in $\mathrm{kg}$. Change in mass of concrete specimens after completion of exposure of corresponding age is evaluated. For evaluating the change in compression strength of concrete specimen after completion of exposure age in acid, the specimens are kept in saturated surface dry (SSD) condition. 
Details of acid exposure test parameters are given in Table XIV. The concrete specimen size is $150 \mathrm{~mm} \mathrm{X} 150 \mathrm{~mm} \mathrm{X}$ $150 \mathrm{~mm}$ for this test.

TABLE XIV DETAILS OF ACID RESISTANCE TEST

\begin{tabular}{|c|c|c|c|}
\hline $\begin{array}{c}\text { Parameters to } \\
\text { Study }\end{array}$ & $\begin{array}{c}\text { Acid Solution } \\
\text { Concentration }\end{array}$ & $\begin{array}{c}\text { Exposure } \\
\text { Age } \\
\text { in Days }\end{array}$ & $\begin{array}{c}\text { Total No. } \\
\text { of } \\
\text { Concrete } \\
\text { Cubes }\end{array}$ \\
\hline $\begin{array}{c}\text { Change in } \\
\text { compressive } \\
\text { strength (MPa) }\end{array}$ & $5 \%$ & $\begin{array}{c}7,14,28 \\
\text { days }\end{array}$ & \multirow{2}{*}{105} \\
\cline { 1 - 2 } $\begin{array}{c}\text { Change in } \\
\text { mass (Kg) }\end{array}$ & $5 \%$ & $\begin{array}{c}7,14,28 \\
\text { days }\end{array}$ & \\
\hline
\end{tabular}

\section{E. Water Absorption Test}

This test is done to know the relative porosity or permeability characteristics of the concrete. The test is carried out after 28 days of moist curing. The concrete specimens used for this test are $150 \mathrm{~mm}$ X $150 \mathrm{~mm}$ X 150 $\mathrm{mm}$ size cubes. The percentage absorption [6] is calculated using Eq. below.

Where,

$$
\text { Absorption }(\%)=\left(\mathrm{W}_{2}-\mathrm{W}_{1}\right) / \mathrm{W}_{1} \times 100
$$

$\mathrm{W}_{1}=$ weight of concrete specimen after complete drying at $105 \mathrm{C}$

$\mathrm{W}_{2}=$ final weight of surface dry concrete specimen after immersion in water at least 24 hours

The concrete specimens are first dried for 24 hours at $105 \mathrm{C}$ in oven. The concrete specimens are removed from the oven and weighed which is considered as initial weight $\mathrm{W}_{1}$. They are immersed in water again for 24 hours.

TABLE XV DETAILS OF WATER APSORPTION TEST

\begin{tabular}{|c|c|c|c|}
\hline $\begin{array}{c}\text { Para Meters } \\
\text { to Study }\end{array}$ & $\begin{array}{c}\text { Period in } \\
\text { Oven } \\
\text { for Complete } \\
\text { Dry }\end{array}$ & $\begin{array}{c}\text { Duration of } \\
\text { Immersion } \\
\text { in Water Tank }\end{array}$ & $\begin{array}{c}\text { No. of } \\
\text { Concrete } \\
\text { Cubes }\end{array}$ \\
\hline $\begin{array}{c}\text { Change in } \\
\text { Mass (Kg) }\end{array}$ & 24 hours & 24hours & 12 \\
\hline
\end{tabular}

\section{CONCLUSION}

The partial replacement of dredged sea sand with M-Sand and Natural sand improve the grade of aggregate for use in concrete. The compressive strength of concrete specimens made with dredged sea sand was equal compared to river sand. The strength of concrete made with $75 \%$ was found to be near to the strength of concrete made with the M-Sand. The flexural strength of the concrete made with dredged sea sand was also equal compared to the concrete made with the river sand. The flexural strength of concrete made with $75 \%$ graded sand was found to be near to the flexural strength of concrete made with M-Sand. The percentage of water absorption for concrete made with dredged sea sand was high and the concrete made with $75 \%$ graded sand shows less water absorption compared with concrete specimen with $25 \%$ and $50 \%$ grades sand.

\section{REFERENCES}

[1] S. S. Arthria and S. Neethu, "Strength and Durability of Concrete Using Dredged Sea Sand as Partial Replacement of M-sand", International Journal of Research in Engineering and Technology, Vol. 4, No. 6, pp. 180-183, June 2015.

[2] A. Ashok Kumar, B. Subashini, G. Sivaranjani, G. Dhanalakshmi, K.Gayathri, A. Srimathi and C. Revathi, "Experimental Investigation of Sea Sand for Construction Purposes”, Indian Journal of Science and Technology, Vol. 9, No. 11, March 2016, DOI: 10.17485.

[3] Dar Dolage, M. G. S. Dias and C. T Ariyawansa, "Offshore Sand as a Fine Aggregate for Concrete Production”, British Journal of Applied Science \& Technology, Vol. 3, No. 4, pp. 813-825, May 2015.

[4] C. G. Girish, D. Tensing and K. L. Periya, "Dredged Offshore Sand as a Replacement for Fine Aggregate in Concrete", Journal of Mining Science and Technology, Vol. 21, pp. 123-127, July 2016.

[5] IS 383: 1970, Indian Standards Specification for Coarse and Fine Aggregate from Natural Source for Concrete.

[6] IS 2386: 1963, (Part III) Indian Standards Methods of Test for Aggregate for Concrete.

[7] IS: 10262-2009 and SP 23:1982. Recommended Guidelines for Concrete Mix. Bureau of Indian Standards, New Delhi.

[8] M. Karthikeyan and V. Nagarajan, "Feasibility Study on Utilization of Marine in Concrete for Sustainable Development”, US-China Education Review A, ISSN 2161-623X, Vol. 3, No. 5, pp. 325-331, May 2016.

[9] Salmabanu Luhar and Urvashikhandelwal, "A Study of Durability of Dredged Marine Sand Concrete”, Journal of Geological Society of Sri Lanka, Vol. 16, pp. 109-117, 2015.

[10] S. Narasimhan and S. Arivalagan, "Reprocess of Dredged Sea Settled Particles from Coastal Areas as Partial Replacement with River Sand in Concrete", Research Journal of Environmental and Earth Sciences, Vol. 4, No. 12, pp. 1071-1078, December 2016. 